\title{
Transforming the Greek Cycladic islands into a wind energy hub
}

Eleni Zafeiratou MEng, MSc

Energy Institute, University College London, London, UK (corresponding author: e.zaferatou@ucl.ac.uk)
Catalina Spataru MSc, PhD

Energy Institute, University College London, London, UK

The interconnection of the Greek Cyclades islands with the mainland national grid system is scheduled to be completed by 2025 . The aim of this project is to improve energy security, reduce costs and carbon dioxide emissions and increase the use of renewable energy resources. Enhancement of the current isolated power networks through interconnectors will allow higher integration of intermittent wind energy loads to the system. This paper analyses an action plan alongside its economic and carbon dioxide emissions impact, between 2017 and 2030, for the implementation of $258.6 \mathrm{MW}$ wind farms in the region, the equivalent of $772.5 \mathrm{GWh} /$ year according to the Weibull wind speed distribution analysis. The estimated average investment return rate for wind projects equals $23 \%$. This is calculated using a life cycle cost analysis. The average cost of energy by using the International Energy Agency methodology equals $€ 80.9 / \mathrm{MWh}$. This paper concludes that the Cyclades interconnection will assist in transforming the region into a wind energy hub, with zero carbon dioxide emissions, allowing electricity exports of $101 \mathrm{GWh} / \mathrm{year}$ to the Greek mainland, while reducing the total electricity costs by $€ 1.4$ billion from 2017 to 2030 .

\section{Notation}

c Weibull scale parameter

$C_{\mathrm{f}} \quad$ capacity factor

$C_{\mathrm{I}} \quad$ capital cost

$D_{t} \quad$ decommission costs of year $t$

Dep $_{t}$ depreciation of year $t$

e share of the equity in the total budget

$E_{t} \quad$ electricity generated of year $t$

Ebitda $_{t}$ earnings before interest, taxes, amortisation and depreciation

$F_{t} \quad$ fuel cost of year $t$

$f(v) \quad$ Weibull two-parameter function

$h \quad$ annual hours (8760)

Int $_{t} \quad$ interest rate of year $t$

$k$ dimensionless Weibull shape parameter

$L \quad$ energy loss

$N_{\mathrm{w}} \quad$ number of wind turbines of year $t$

$O_{t} \quad$ operational expenses of year $t$

$P_{\text {avg }} \quad$ average power output

$P_{\text {nom }} \quad$ nominal or rated power of a wind turbine

$R_{\mathrm{IR}} \quad$ internal rate of return

$r_{\mathrm{e}} \quad$ equity internal rate of return

tax tax rate

$t \quad$ year the cost occurs

$T \quad$ total lifetime of the project

$v_{\mathrm{c}} \quad$ cut-in wind speed of a wind turbine

$v_{\mathrm{f}} \quad$ cut-out wind speed

$v_{\mathrm{r}} \quad$ nominal or rated wind speed

$v_{\mu} \quad$ mean wind speed

$z_{0} \quad$ mean roughness length

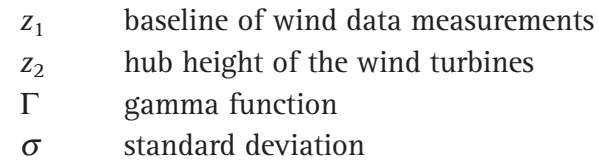

\section{Introduction}

Europe consists of 286 main islands, with $2 \%$ of its population living on them (Eurelectric, 2012). In Europe, Greece has the largest number of islands, almost 3000 , accounting for $20 \%$ of the Greek land area (MEECC, 2014a). Among them, only 86 are residential areas and 28 are interconnected with the national power grid. Greece is a unique European example of numerous isolated power networks concentrated in the Aegean Sea. Most of the non-interconnected islands (NIIs) are grouped in three major prefectures: South Aegean, including the Cyclades and Dodecanese Islands; North Aegean; and Crete.

The Greek government aims to interconnect the majority of the islands with the Greek mainland by 2030 (NTUA, 2008). Given the current unstable economic circumstances in Greece, the entire plan will be further delayed; however, the first project for the interconnection of the Cycladic islands has been recently approved and is currently under implementation.

This study focuses on the Cycladic island complex because it puts forward a test-bed research facility of a newly interconnected area with high renewable energy potential. Located south-east of the mainland, the Cyclades include 27 islands with 118667 inhabitants (Hellenic Statistical Authority, 2011). From these, currently only Andros, Tinos and Kea have been interconnected 


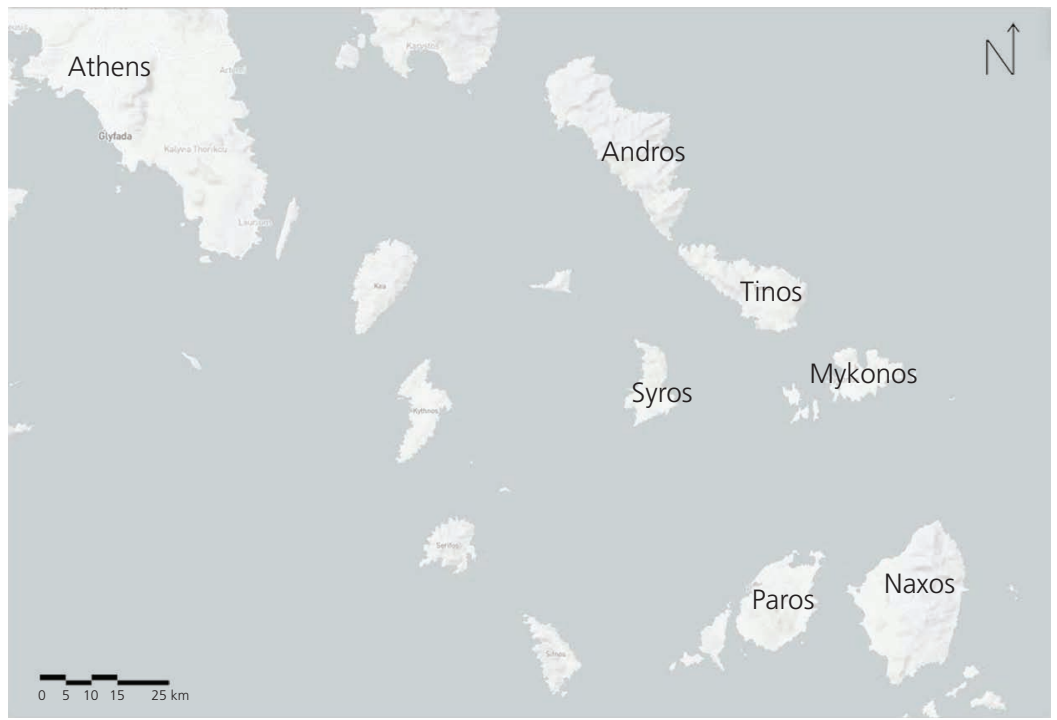

Figure 1. Map of islands included in the Cycladic islands interconnection

\begin{tabular}{lrcrr}
\hline APS & Population & Area: $\mathrm{km}^{2}$ & $\begin{array}{c}\text { Capacity of thermal } \\
\text { power units: MW }\end{array}$ & $\begin{array}{c}\text { Capacity of renewable } \\
\text { resources: MW }\end{array}$ \\
\hline Andros & 9170 & $379 \cdot 2$ & $18 \cdot 1$ (as supplementary source) & $2 \cdot 65$ \\
Tinos & 8590 & $194 \cdot 6$ & $39 \cdot 7$ & $3 \cdot 15$ \\
Syros & 21507 & 84 & $49 \cdot 84$ & $3 \cdot 83$ \\
Mykonos & 10134 & 105 & $73 \cdot 72$ & $2 \cdot 24$ \\
Paros-Naxos and others & 34928 & 798 & $181 \cdot 36$ & $17 \cdot 17$ \\
Total & 84329 & $1560 \cdot 8$ & $23 \cdot 04$
\end{tabular}

Table 1. Characteristics of islands included in the Cyclades interconnection

to the national power system. Electricity demand is met in the region mainly by the oil-burning autonomous power systems (APSs), using imported diesel or heavy fuel oil as resources, with a high environmental and cost impact on the whole country. In order to achieve the $27 \%$ increase in renewable energy generation by 2030 (European Commission, 2009, 2014), the upgrade of the local and national energy sectors is essential. The upcoming interconnection of the Cyclades supports large-scale wind energy development and could play a key role in the power sector improvement.

The Cyclades interconnection project includes Syros, Mykonos, Paros and Naxos and also the interconnected islands of Andros and Tinos, as illustrated in Figure 1. In these islands, with the exception of Andros and Tinos, electricity is supplied by three APSs with a total capacity of $181 \cdot 36 \mathrm{MW}$ (Table 1). Power units are located in Syros, Mykonos and Paros, which is interconnected with Naxos and with a number of other

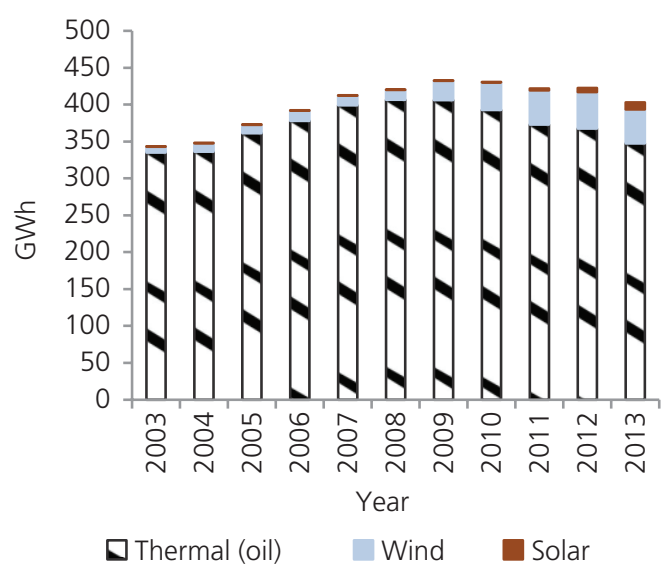

Figure 2. Power generation from 2000 to 2013 in Syros, Mykonos and Paros APSs (data source: HEDNO $(2013,2014)$ ) 


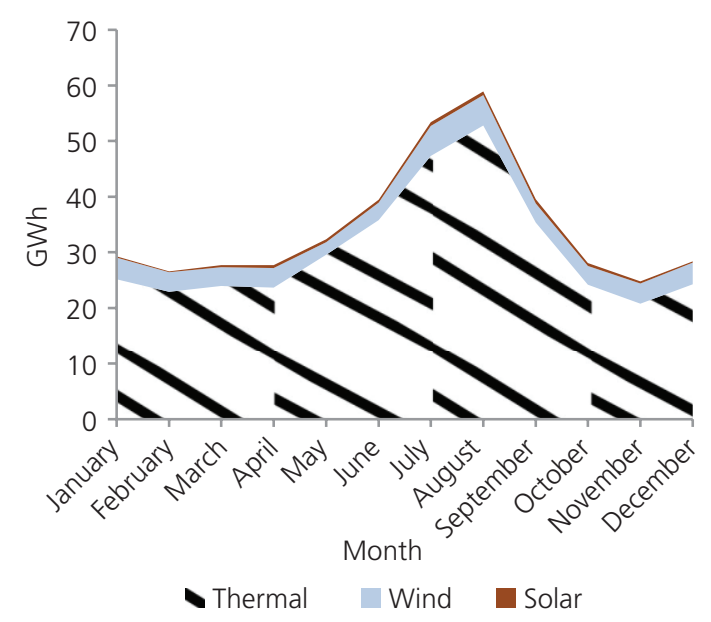

Figure 3. Average monthly demand profiles from 2000 to 2013 in Syros, Mykonos and Paros APSs (data source: HEDNO (2014))

smaller islands in which power is supplied by the same oil-fired power unit.

Power generation in the NIIs (excluding Andros and Tinos) has grown gradually, seeing an increase of $25 \cdot 5 \%$ between 2003 and 2010. From 2010 and onwards, power generation experienced a slight decrease of $6.4 \%$ due to the economic recession (Figure 2). The average monthly power generation profiles display considerable discrepancies, with high peaks in summer months due to high levels of tourism. This divergence can reach up to $52.6 \%$ between August and December, as shown in Figure 3. High levels of energy demand during the summer months could pose threats to the reliability of the power systems, resulting in occasional power cuts.

Renewable energy penetration enacted by Laws 3468 (Hellenic Republic, 2006) and 3851 (Hellenic Republic, 2010) focused on accelerating renewable energy in Greece. A gradual growth until 2013 is recorded, where it reached a $13 \cdot 8 \%$ share of the total power mix. Although the Cyclades area has an outstanding wind potential which could cover large-scale development, integration of wind energy is limited due to technical, social and economic constraints of isolated power grids.

Assuming that the interconnection has already taken place, this study explores a future action plan assessing the economic and carbon dioxide emissions impact of the islands' transformation into a wind energy hub. Here, a wind energy hub is considered as an area that generates and exports large amounts of wind energy through interconnectors.

\section{The interconnection of the Cycladic islands with the mainland}

\subsection{Technical description}

The interconnection project of the Cyclades islands with the mainland proposes the construction of submarine grids interconnecting Syros, Mykonos, Paros and Naxos with Tinos Island and the Greek mainland (RAE, 2004), as illustrated in Figure 4. Firstly, the four NIIs are interconnected and then Andros and Tinos interconnection

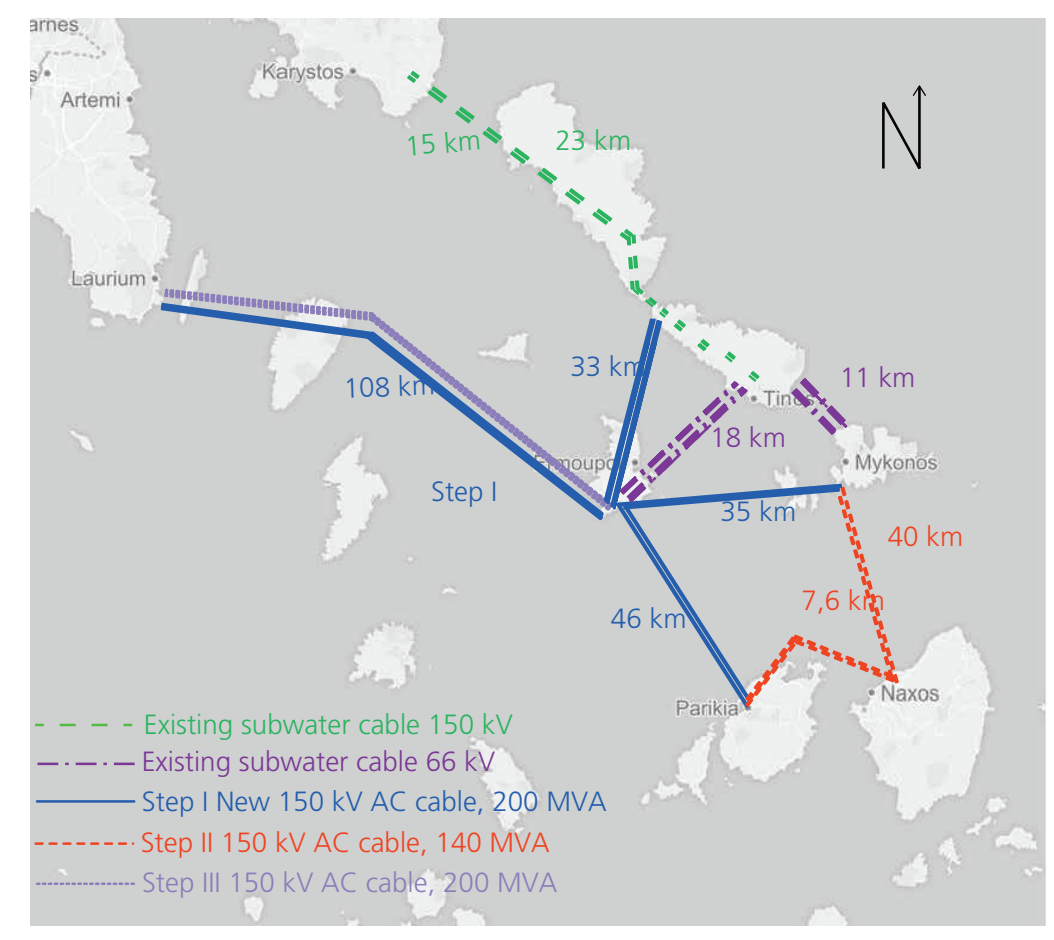


takes place by way of a second route enabling the shutdown of the existing thermal power plants operating as a main power source in the NIIs and as a backup source in Andros. The Cyclades interconnection is split into three steps (HIPTO, 2013, 2014).

Step I (estimated to be completed by 2017).

(a) Syros will be interconnected with the Greek mainland at Lavrio's substation, with a pair of submarine cables, $108 \mathrm{~km}$ long, with the following features: three-phase alternating-current (AC) power cord, transmission voltage of $150 \mathrm{kV}$ and a nominal capacity of 200 MVA each, with plastic insulation cross-linked polyethylene (XLPE) in simultaneous parallel function.

(b) Syros will be interconnected with the northern part of Tinos through a $33 \mathrm{~km}$ long submarine cable having the same features.

(c) Syros will be interconnected with Paros through a $46 \mathrm{~km}$ long radial connection with a submarine cable, with the same features and nominal capacity of 140 MVA.

(d) Syros will be interconnected with Mykonos through a $35 \mathrm{~km}$ long radial connection with a submarine 140 MVA cable.

Through this plan, Syros, Mykonos and Paros will be interconnected with the mainland and will allow the implementation of renewable energy investments with capacity equal to approximately $170 \mathrm{MW}$ under $\mathrm{N}$ conditions and $120 \mathrm{MW}$ under N-1 conditions. Gas insulation substations, $20 / 150 \mathrm{kV}$, will be constructed in Lavrio and on Tinos, Syros, Paros and Mykonos Islands. Terrestrial installations on the islands requiring a new transmission system of $(20 \mathrm{kV})$ will be mainly underground in order to avoid natural and aesthetical disturbance in the area (Zafeiratou and Spataru, 2015).

Step II (estimated to be completed by 2022). This phase includes further expansion of the interconnections with a submarine cable (three-phase AC power cord transmission with a voltage of $150 \mathrm{kV}$ and with a nominal capacity of 140 MVA, with XLPE plastic insulation), from Paros to Naxos $(7 \cdot 6 \mathrm{~km})$ and Naxos to Mykonos (40 km).
Step III (estimated to be completed by 2025). This phase includes the reinforcement of the single cable placed in step I. The upgrade of the network will include the immersion of a second AC cable between Lavrio and Syros.

\subsection{Cost of the interconnection}

The total cost of the project is $€ 400.17$ million. Phase A will cost $€ 250 \cdot 13$ million, accounting for more than $62.5 \%$ of the total budget. The most expensive part is the submarine cabling, accounting for more than $86 \%$ of the total cost. The annual operation cost for the interconnectors is estimated to be $€ 1.3$ million (HIPTO, 2013). A socio-economic analysis conducted by the Hellenic Independent Power Transmission Operator (HIPTO, 2013) showed that the net present value (NPV) of the interconnection project is $€ 341-371$ million and the internal rate of return $\left(R_{\mathrm{IR}}\right)$ is $17 \cdot 87 \%$ between 2017 and 2038 . These two factors prove that this project is a profitable solution for a future integrated, secure and sustainable system in the area.

\section{Wind energy sector in the Cycladic islands}

\subsection{Wind data}

The six islands examined in this paper possess high wind potential with annual wind speed measurements varying between 6 and $12 \mathrm{~m} / \mathrm{s}$ (at $100 \mathrm{~m}$ height) according to the Regulatory Authority for Energy (RAE, 2014a). Spatial distribution maps for the area indicate that the frequency of occurrence of wind speed faster than $8 \mathrm{~m} / \mathrm{s}$ is $35 \%$ and for wind speed faster than $11 \mathrm{~m} / \mathrm{s}$ is $8 \%$. The histograms in Figure 5 show the hourly wind velocity, $10 \mathrm{~m}$ above the sea (CRES, 2003; Communication Systems et al., 2004; RAE, 2014a). The main direction of wind speed is principally north, as illustrated in Figure 6. The Cyclades region has been characterised by a ministerial decision as a highly suitable zone for wind energy investments among other areas in Greece (Hellenic Republic, 2008).

\subsection{Barriers to wind energy development}

Table 2 shows that the Cycladic islands have already concentrated wind energy developers' attention, with more than $564 \mathrm{MW}$ of

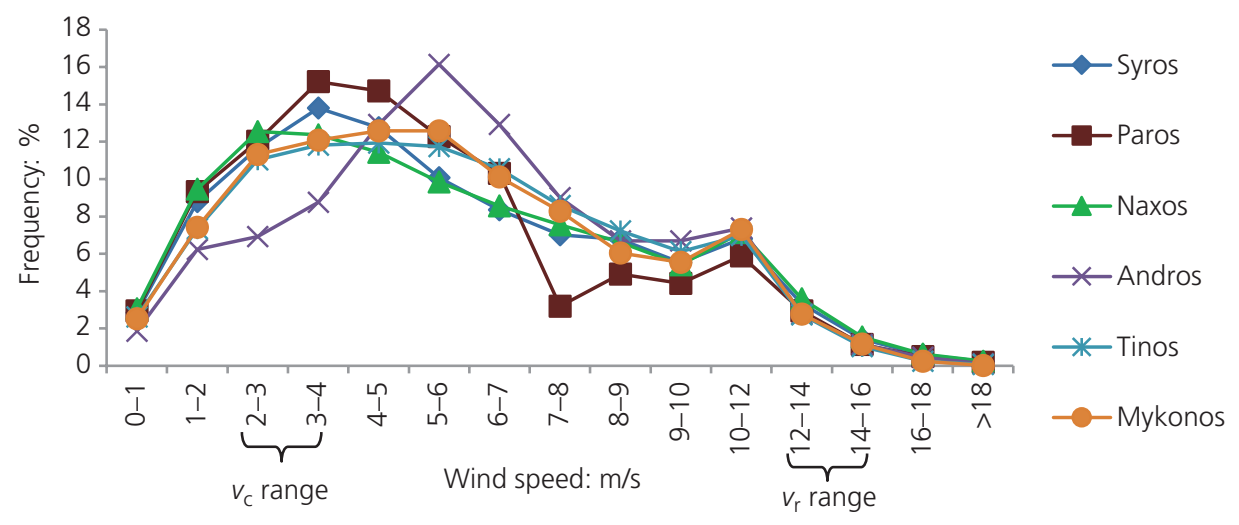

Figure 5. Histograms including hourly wind measurements at 10 m height from 1999 to 2004 (data source: Communication Systems et al. (2004)) 


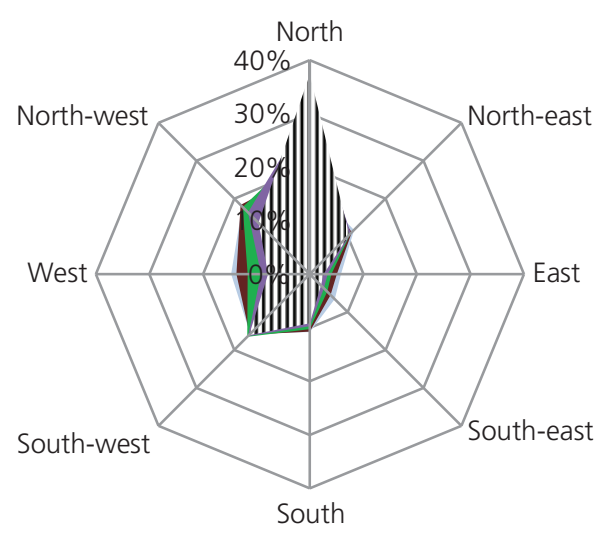

$0-4 \mathrm{~m} / \mathrm{s}$

8-12 m/s

$12-16 \mathrm{~m} / \mathrm{s}$

$>16 \mathrm{~m} / \mathrm{s}$

Figure 6. Wind rose including hourly wind measurements at $10 \mathrm{~m}$ height from 1999 to 2004 (data source: Communication Systems et al. (2004))

licensed wind farms. Due to an assortment of barriers (technical, social and economic), the excellent wind potential of the area remains unexploited, as currently only $14 \cdot 8 \mathrm{MW}$ has been implemented.

The most significant obstacle is related to the intermittency of wind energy. According to technical regulations, the island system operator does not allow wind energy integration to exceed a limit of $30 \%$ of the hourly load demand in order to secure the stability of the electrical network and to prohibit abrupt frequency alterations (Hatziargyriou et al., 2012; Maroulis, 2013). This limitation can be surpassed only either by employing energy storage systems which allow shifting power supply to peak demand periods or with interconnectors.

However, even in the interconnected islands, wind energy development remains at low levels due to social acceptance. Several wind projects have been delayed in completing the licensing procedure due to the local society's reactions. The main concerns of the islands' inhabitants is related to landscape and environmental disturbance, visual impact, difficulties in harmonisation between traditional architecture and wind turbines (WTs) and noise disruption (Torres Silva, 2008). According to RAE, the maximum limit of wind installations in the Cyclades is $0.53 \mathrm{WT} / \mathrm{km}^{2}$. Furthermore, visual impact and noise disturbance are also protected by restricting the minimum distance from residential areas and the coastline to $1 \mathrm{~km}$ (Hellenic Republic, 2008). The maximum number of a typical WT (rotor diameter equal to $85 \mathrm{~m}$ (Voltera, 2013)) which can be installed in each island is presented in Table 2, demonstrating that there is sufficient margin for the implementation of new wind farms.

Although visual impact and noise disturbance are properly addressed, emphasis is placed on the environmental impact of large-scale wind projects. There is scientific evidence that WTs have no effect on agricultural and farming activities or birds fatality (Binopoulos and Haviaropoulos, 2016), in particular given the fact that new transmission lines on islands will be underground. Considering

\begin{tabular}{lccc} 
Island & Current: MW & Licensed: MW & W/T limit \\
\hline Syros & $2 \cdot 84$ & $12 \cdot 2$ & 36 \\
Mykonos & 1.23 & 4.8 & 56.07 \\
Paros & - & $75 \cdot 6$ & $105 \cdot 17$ \\
Naxos & $8 \cdot 76$ & $68 \cdot 2$ & 67.4 \\
Andros & 1.575 & $348 \cdot 8$ & 202 \\
Tinos & 0.4 & 55 & 70 \\
Total & 14.805 & 564.6 &
\end{tabular}

Table 2. Overview of current, licensed wind projects and W/T maximum limit (data source: Regulatory Authority for Energy (2014a), Energy Register (2014), MEECC (2014b))

deforestation, the Cycladic islands are mainly occupied with low trees and bushes, so deforestation is limited, although careful selection of the site is required. Consequently, each project is accompanied according to Law 4014 (Hellenic Republic, 2011a) by an environmental impact assessment (EIA) study which has been approved by the state and a restoration study including the wind site, access roads and substation/grid installations.

Additionally, the islands' residents relate large-scale wind implementation to reduction in tourism; however, this is a completely unjustified argument (Regeneris Consulting and the Tourism Company, 2014; The Tourism Company, 2012). In order to overcome this barrier, it is necessary to educate local residents in terms of climate change implications and provide incentives such as decrease in power cost, local society involvement and donations.

The economic recession in Greece along with the continuously changing tax system increases the risk investment factors and discourages investors from investing. As a result of the current economic conditions, in 2013, the government reduced the feed-in tariff (Fit) retroactively mainly for solar energy (29.5\% on average), but wind also suffered reductions of approximately $6 \cdot 4 \%$ (Hellenic Republic, 2014a). This has brought cancellation of several scheduled projects as well as deterioration of the Greek investment environment. This challenge could be addressed by initiatives combing European, national and private sector economic support.

\section{Action plan for wind energy deployment in the region of Cyclades}

\subsection{Wind energy generation}

\subsubsection{Assumptions}

The Cyclades interconnection has been estimated to allow the gradual penetration of approximately $250 \mathrm{MW}$ (HIPTO, 2013). According to this, an action plan was employed for transforming the Cyclades into a wind energy hub.

The following assumptions have been taken into consideration: the barriers' decline, the islands' maximum target for renewable energy integration, licensed projects and their characteristics, the 
nominal capacity of submarine cables and the islands' size and wind potential. Andros, given that it possesses the highest wind potential, will achieve its target of installing renewable energy resources, sharing $34 \cdot 5 \%$ of power generation in the area by 2030 . Naxos and Paros Islands possess a portfolio of large-scale projects that are already licensed; therefore, new projects will slightly exceed targets as presented in the following discussion. On the other hand, Mykonos and Syros, being the two smallest islands and with limited land areas, have licensed only small-scale projects and, consequently, limited wind energy activity is proposed.

The projects' timescale shown in Figure 7 has always been determined in line with the interconnection schedule, alongside maturity factors for the projects. Maturity factors are a criterion showing the licensing stage of the wind projects, ranging between 1 and 3 with an increasing scale. Stage 1 declares that the project has received the first licence, 'licence of energy production' from RAE. Stage 2 includes projects with an approved EIA. Stage 3 is related to the 'installation licence' for the last phase before construction. The proposed plan does not include all licensed projects (Table 2), but those projects closest to the implementation stage were selected, in order to follow a realistic plan of approximately $250 \mathrm{MW}$ development. Targets have been achieved, reaching 258.6 MW by 2030. By 2025, wind energy capacity is still low, due to the projects' capacity, timeline and maturity, which do not allow the implementation of additional farms in order to fill the 30 MW gap.

An overview of the development of wind farms in each island, transforming the area into a wind energy hub, is illustrated in Figure 8 , showing existing and new projects according to the action plan.

\subsubsection{Methodology}

A methodology for estimating future wind power generation was applied based on the Weibull wind speed probability density function, which shows the probability of observing wind speed $(v)$ based on the data set provided in Section 3.1 (Figure 8). According to the literature review, several relevant studies (Celik, 2003; Chang et al., 2003; Lu et al., 2002; Lun and Lam, 2000; Persaud et al., 1999; Seguro and Lambert, 2000; Weisser, 2003) used the twoparameter Weibull wind speed distribution to estimate wind potential as a commonly accepted and accurate method for wind energy analysis. Given the wind data in Section 3.1, $k$, which is the dimensionless Weibull shape parameter, and $c$, which is the Weibull scale parameter $(\mathrm{m} / \mathrm{s})$, were estimated for each project on each island based on the following mathematical formulation.

The Weibull two-parameter function is calculated as follows

1. $f(v)=\frac{k}{c}\left(\frac{v}{c}\right)^{k-1} \exp \left[-\left(\frac{v}{c}\right)^{k}\right]$

where $k$ and $c$ are

2. $k={\frac{\sigma}{v_{\mu}}}^{(-1 \cdot 086)}(1 \leq k \leq 10)$

3. $c=\frac{v_{\mu}}{\Gamma\left(1+\frac{1}{k}\right)}$

$v_{\mu}$ is the mean wind speed of the frequency table including $n$ measurements and standard deviation $\sigma$ of the wind speed data as presented in the following

4

$$
v_{\mu}=\frac{1}{n} \sum_{i=1}^{n} v_{i}
$$

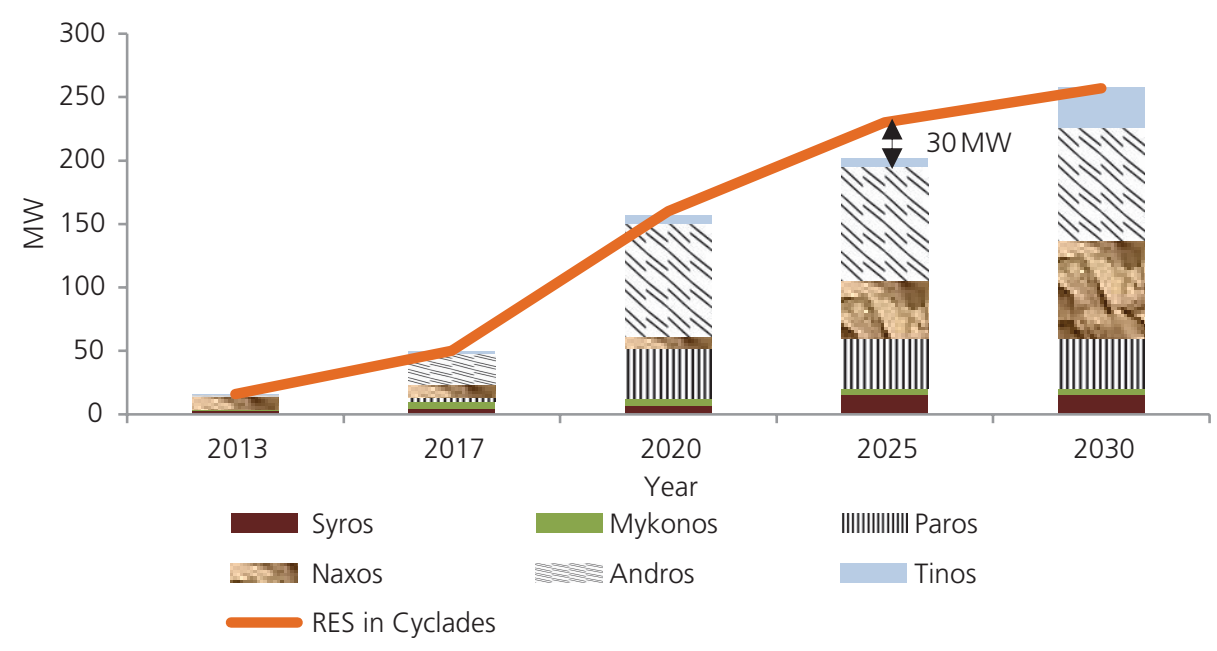

Figure 7. Gradual renewable energy integration into the system from 2013 to 2030 


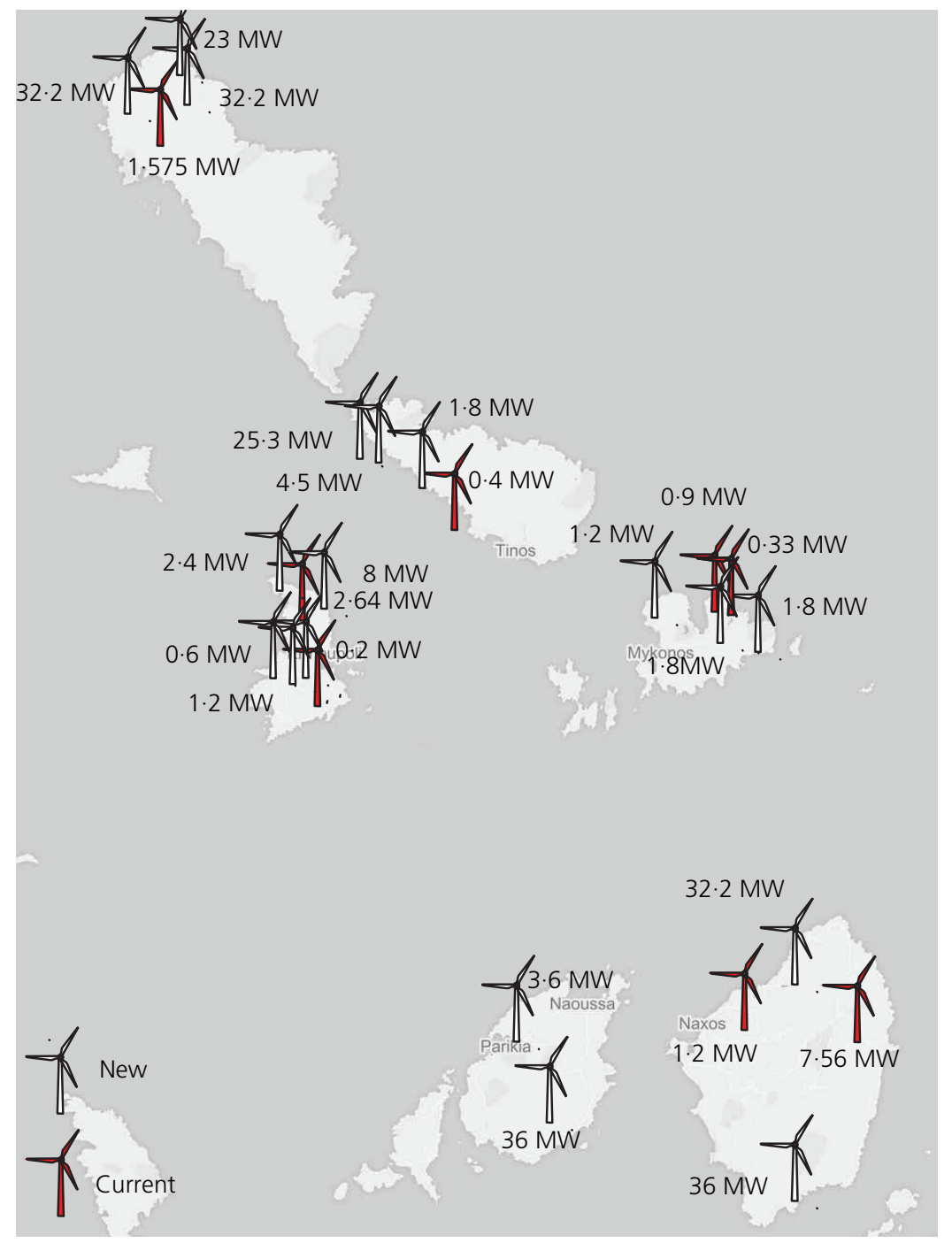

Figure 8. The Cycladic islands as a wind hub

5 .

$$
\sigma=\sqrt{\frac{1}{n-1} \sum_{i=1}^{n}\left(v_{i}-v_{\mu}\right)^{2}}
$$

Finally, the gamma function of $(x)$ (standard formula) is calculated as 6.

$$
\Gamma=\int_{0}^{\infty} e^{-u} u^{x-1} \mathrm{~d} u
$$

As the hub heights of the WTs $\left(z_{2}\right)$ are higher than $10 \mathrm{~m}\left(z_{1}\right)$, which is the baseline for collected data, the wind speed $\left(v_{2}\right)$ was extrapolated to the relevant hub height according to Equation 7. Based on the area characteristics, a mean roughness length in the wider area of $z_{0}=0 \cdot 20$ is assumed, since the terrain consists of low bushes and trees (Ragheb, 2015)

7. $v_{2}=v_{1}\left[\frac{\ln \left(z_{2} / z_{0}\right)}{\ln \left(z_{1} / z_{0}\right)}\right]$

Following the Weibull distribution methodology, the $k$ and $c$ factors are used to estimate the average power output $P_{\text {avg }}$ and the capacity factor $C_{\mathrm{f}}$ for every site and WT as described from the following equations presented by Akpinar and Akpinar (2005)

$$
P_{\mathrm{avg}}=\left[\frac{e-\left(v_{\mathrm{c}} / c\right)^{k}-e-\left(v_{\mathrm{r}} / c\right)^{k}}{\left(v_{\mathrm{r}} / c\right)^{k}-\left(v_{\mathrm{c}} / c\right)^{k}}\right]-e-\left(\frac{v_{\mathrm{f}}}{c}\right)^{k}
$$

8. for $v_{\mathrm{c}} \leq v \leq v_{\mathrm{r}}$ 


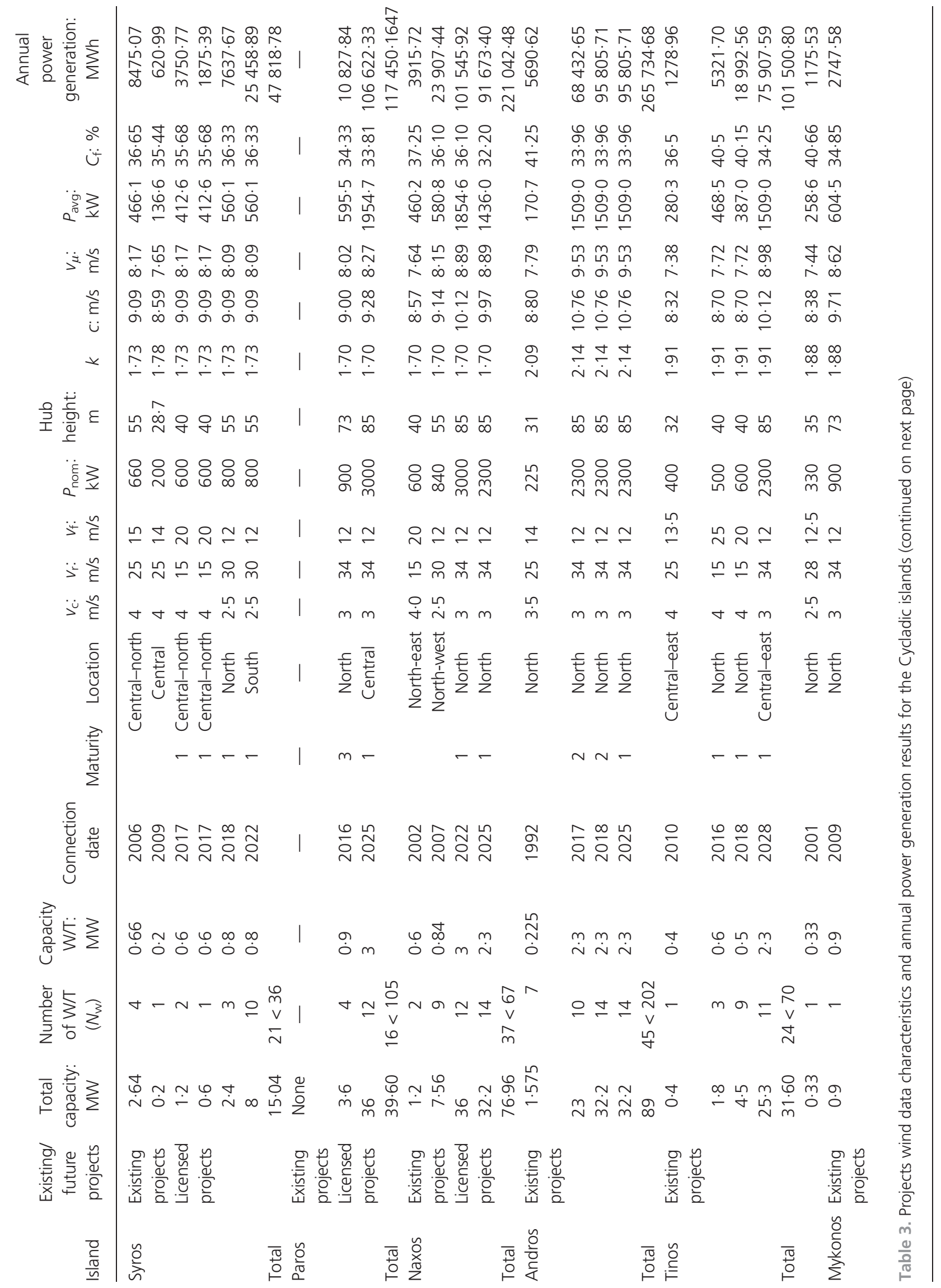


where $v_{\mathrm{c}}$ is the cut-in wind speed of a WT, $v_{\mathrm{r}}$ is the nominal or rated wind speed and $v_{\mathrm{f}}$ is the cut-out wind speed as indicated in Table 3

9. $C_{\mathrm{f}}=\frac{P_{\text {avg }}}{P_{\text {nom }}}($ Betz limit $)$

where $P_{\text {nom }}$ is the nominal or rated power of a WT. The Betz limit factor was configured from Albert Betz to be 0.593 and is the theoretical maximum coefficient of power for any WT (Ragheb, 2014).

In order to estimate the final annual power output, a number of additional losses $(L)$ were incorporated, such as: average losses due to WT availability (3\%), altitude difference $(3 \%)$, transmission losses through the grid and substations (5\%) and losses due to wind speed hysteresis, balance of plant availability, turbine performance and environmental losses $(1 \cdot 5 \%)$, which configured the final capacity factor $C_{\mathrm{f}}$ of every wind project (DNV GL personal communication, 2015)

10. annual power generation $=L C_{\mathrm{f}} h P_{\text {nom }} N_{\mathrm{w}}$

where $h$ is the annual hours (8760) and $N_{\mathrm{w}}$ is the number of WTs.

\subsection{Life cycle costs analysis \\ 4.2.1 Assumptions}

The literature demonstrates a number of studies on WT life cycle cost analysis - for example Celik (2003), Nilsson and Bertling (2007), Tai and Wen-rui (2009), Puglia (2013) and Badgujar et al. (2013). This section shows the outline, including stages and tasks, required to complete a wind farm project in the Cycladic islands. The wind energy project's life cycle analysis consists of four different stages as depicted in Figure 9. The duration of each stage was estimated based on data presented by RAE considering licensing and power purchase agreements (RAE, 2014b). Each stage incorporates a realistic estimation of different costs for wind proct implementation. The values are indicative since each wind project consists of different uncertain characteristics - for example length of roads, availability of squares for WT assembling, private/public land, type of WT and labour expenses. In order to mitigate these uncertainties, data sources for the last 5 years were identified within the Greek construction and energy sectors.

Project development expenses are related mainly to the measurement campaigns and EIA studies, which are included in the licensing and financing stage. The major expenses are included in the construction phase, with WT supply and transportation to the islands occupying approximately $80-85 \%$ of the total budget of the project. The construction phase requires electrical engineering works related to WT connection, test, cabling and civil engineering works. The interconnection costs 


\section{Offprint provided courtesy of www.icevirtuallibrary.com} Author copy for personal use, not for distribution

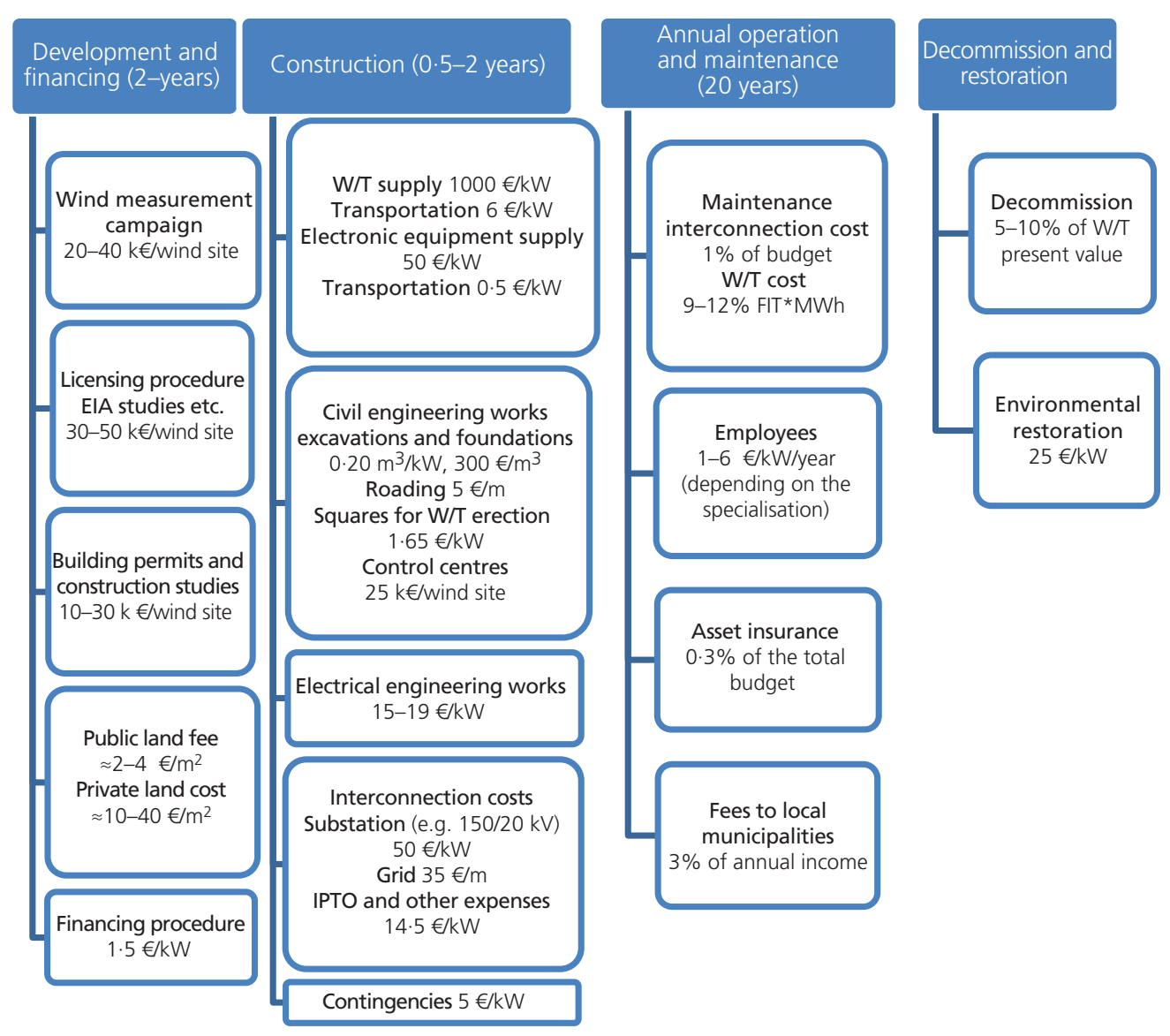

Figure 9. Tasks and costs incorporated in the life cycle analysis (data sources: Nexans (2011); Gras Savoye Willis (2012); Alstom (2013); Enercon (2013); ABB (2013); Gamesa (2014); HIPTO

(2014); DNV GL (personal communication, 2015))

vary depending on the size of the project, the distance from the grid and the requirement of a new substation, mainly in largescale projects. Environmental costs are taken from the EIA studies for restoration and decommission stages. During the operation, the highest cost is related to maintenance and usually formed as a fixed price per kilowatt-hour given by the WT manufacturer. Furthermore, $3 \%$ of the net wind energy annual turnover is granted directly to the local municipalities to support local population. Depending on the WT size, decommission costs vary between 5 and $10 \%$ of the WT cost. In the economic analysis, the decommission costs were isomerised during the 20-year project lifetime. Prices are configured according to the Fit mechanism currently in issue in Greece, being $€ 105 / \mathrm{MWh}$ (Hellenic Republic, 2014a) and remaining stable for 20 years.

Financial indicators such as tax and depreciation were integrated in the economic analysis according to the Greek legislation framework, assuming that they remain stable during the lifetime of the project (Table 4). The economic analysis included assumptions related to project financing through a loan, including parameters reflecting the current financing environment in Greece and Europe. Inflation and interest rates were estimated assuming that the current volatile economic circumstances, resulting in negative inflation factors (Bank of Greece, 2015), will be gradually alleviated.

\subsubsection{Key investment indicators}

In order to assess the viability of wind projects from an investor perspective, principal economic factors of the investment were estimated as the internal rate of return $\left(R_{\mathrm{IR}}\right)$ and the equity internal rate of return $\left(r_{\mathrm{e}}\right) . R_{\mathrm{IR}}$ is the interest rate, which makes the NPV of the project equal to zero, and $r_{\mathrm{e}}$ is the discount rate considering cash flows net of financing, calculated from Equations 11 and 12, respectively. The International Energy Agency method was applied for estimating levelised costs of energy (LCOEs). LCOEs are the total of the discounted costs through the project's lifetime, allotted across the discounted parts of power produced (Equation 13). This provides a more holistic overview of the total costs of a wind project over its life cycle, per unit of power generated, expressed in euros per megawatt-hour (Schwabe et al., 2011). 
Indicator

Interest rate
Tax rate (tax)
Payback period
Grace period
Financing
scheme
Inflation
Depreciation
(Dep)

Value

$5 \%$

26\% (data source: Hellenic Republic (2013))

15 years

2 years

$30 \%$ capital costs and $70 \%$ loan

$0.5 \%$

$10 \% /$ year for machinery, W/T and electronic equipment

4\%/year for civil constructions (data source: Hellenic Republic (2013))
11. $\sum_{t=1}^{T}\left[\operatorname{Ebitda}_{t} /\left(1+R_{\mathrm{IR}}\right)^{t}\right]-C_{\mathrm{I}}=0$

where Ebitda $t$ is the earnings before interest, taxes, amortisation and depreciation; $C_{\mathrm{I}}$ is the total initial investment cost; $t$ is the year that the cost occurs; and $T$ is the total lifetime of the project (20 years).

12. $\sum_{t=1}^{T}\left[\right.$ net profit $\left./\left(1+r_{\mathrm{e}}\right)^{t}\right]-C_{\mathrm{I}} e=0$

where net profit is the earnings after interest, taxes, amortisation and depreciation and $e$ is the share of the equity in the total budget.

$$
\mathrm{LCOE}=\frac{e C_{\mathrm{I}}+\sum_{t=1}^{T}\left\{\begin{array}{c}
{\left[(1-\operatorname{tax})\left(O_{t}+F_{t}+D_{t}\right)\right.} \\
\left.-\operatorname{tax}\left(\mathrm{Int}_{t}+\mathrm{Dep}_{t}\right)\right] /\left(1+r_{\mathrm{e}}\right)^{t}
\end{array}\right\}}{\sum_{t=1}^{T} E_{t}(1-\operatorname{tax}) /\left(1+r_{\mathrm{e}}\right)^{t}}
$$

13.

where tax is the tax rate, $O_{t}$ are the operational expenses for year $t$, $F_{t}$ is the fuel cost (WT include fuel costs only in the transportation and construction phases for machinery), $D_{t}$ is the decommission costs of year $t, E_{t}$ is electricity generated each year, Int $_{t}$ is the interest rate of year $t$ and $\operatorname{Dep}_{t}$ is the depreciation of year $t$.

\section{Results}

\subsection{Wind energy generation}

Table 3 presents the projects' characteristics, results according to the Weibull distribution analysis followed in Section 4.1.2 and the annual power generation output for each project.
Capacity factors for all the projects reached remarkably high efficiency rates between 32 and $41 \%$. The total energy produced from wind resources by 2030 is estimated to be $772.5 \mathrm{GWh}$. The total transformation of the islands' power electricity supply mix is illustrated in Figure 10. While in 2013 almost $89 \%$ of the annual power generation in the area was covered by conventional power sources, this amount is drastically reduced by 2017 to $67 \cdot 7 \%$ in 2017 and by 2025 it will be eliminated. Following 2025, the annual balance of demand and supply will allow export of power from the Cycladic islands to the mainland up to $101 \mathrm{GWh} /$ year by 2030 , creating a wind energy hub in the area. Wind energy development will enhance energy dependency in the region, by replacing imported conventional sources, in parallel with costs and emissions reduction.

\subsection{Life cycle cost analysis}

Costs and investment factors are presented in Table 5, following the mathematical formulation in Section 4.2.2. Wind projects in the Cycladic islands record investment rates ranging between 17 and $32 \%$, while the average $R_{\mathrm{IR}}$ factor is equal to $23 \%$ due to high capacity factors and high Fit. Although $R_{\mathrm{IR}}$ highlights the profitability of a project, investment cases are examined in a more holistic way by evaluating the risk associated with the nature of the project, electricity market regulation and electricity prices.

Figures 11 and 12 compare the $R_{\mathrm{IR}}$ values and LCOEs of the wind projects, demonstrating that highly efficient projects have lower levelised costs per unit of power. LCOE provides a useful indicator for the economic analysis as it correlates power generated with capital costs. In this study, without considering the electricity price values, the average LCOE is equal to $€ 80 \cdot 9 / \mathrm{MWh}$.

\subsection{Electricity market impact}

Power generation cost for Syros, Mykonos and Paros APSs was configured for 2013 as follows: $€ 226 \cdot 58 / \mathrm{MWh}, € 345 \cdot 75 / \mathrm{MWh}$ and $€ 190 \cdot 34 / \mathrm{MWh}$ (Hellenic Republic, 2014b). Electricity cost in these areas is between 2.7 and 5 times greater, compared to the generalised electricity price in the Greek interconnected part, which was $€ 70 \cdot 5 / \mathrm{MWh}$ according to the latest indications in 2013. This difference is subsidised through a cross-subsidisation policy named 'Public Service Obligation', which was initially established in 1999 under Law 2773 (Hellenic Republic, 1999) provisions and amended in 2011 with the current Law 4001 (Hellenic Republic, 2011b). This policy splits extra costs from power generation in the islands among all the Greek energy consumers. For 2013, this cost reached $€ 65 \cdot 3$ million (Hellenic Republic, 2014c).

To project the islands' future power generation costs, an annual growth factor of $2 \%$ was assumed in the fuel price in addition to the annual average inflation factor as proposed by the National Technical University of Athens (NTUA, 2008). Based on the projections for power demand illustrated in Figure 10, Figure 13 compares the cost of a business-as-usual (BAU) scenario where no interconnection and new wind projects are implemented and the action plan proposed including $258.6 \mathrm{MW}$ of new wind projects. 


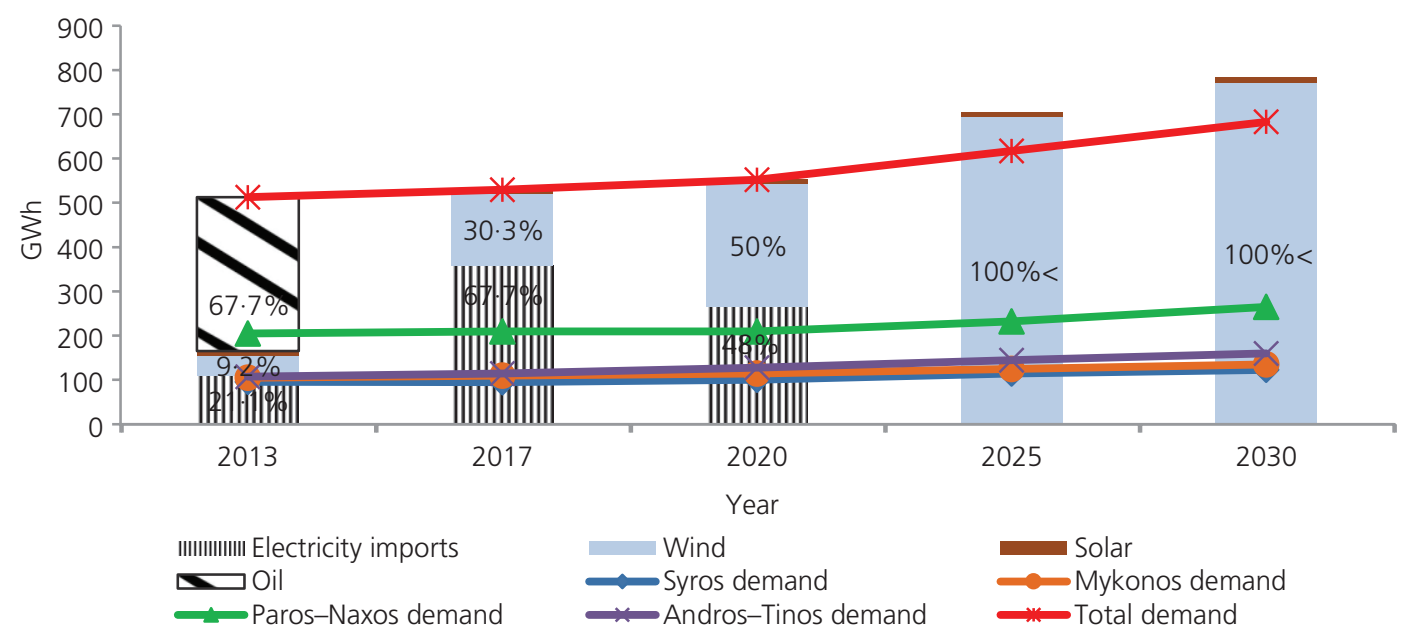

Figure 10. Electricity demand and supply mix in the Cycladic islands from 2017 to 2030

\begin{tabular}{|c|c|c|c|c|c|c|c|c|c|}
\hline Island & $\begin{array}{c}\text { Total } \\
\text { capacity: } \\
\text { MW }\end{array}$ & $\begin{array}{c}\text { Total } \\
\text { investment } \\
\text { cost }\left(C_{1}\right): €\end{array}$ & $\begin{array}{c}\text { Development } \\
\text { costs: } €\end{array}$ & $\begin{array}{c}\text { Annual } \\
\text { operating } \\
\text { costs }(O): €\end{array}$ & $\begin{array}{c}\text { Decommission } \\
\text { costs }(D): €\end{array}$ & Ebitda: $€$ & $\begin{array}{l}\text { Investment } \\
R_{\mathbb{R}}(20 \\
\text { years): \% }\end{array}$ & $\begin{array}{c}\text { Equity } R_{\mathbb{I R}} \\
\left(r_{\mathrm{e}}\right):(20 \\
\text { years): \% }\end{array}$ & $\begin{array}{l}\text { LCOE: } \\
\in / M W h\end{array}$ \\
\hline \multirow[t]{6}{*}{ Syros } & $2 \cdot 64$ & 3306170 & 145000 & 76518 & 184800 & 783774 & 24 & 32 & $76 \cdot 4$ \\
\hline & $0 \cdot 2$ & 306263 & 72500 & 11355 & 14000 & 49956 & 17 & 17 & $105 \cdot 8$ \\
\hline & $1 \cdot 2$ & 1322263 & 75000 & 48153 & 64000 & 359445 & 26 & 34 & $75 \cdot 3$ \\
\hline & 0.6 & 798175 & 72500 & 31476 & 39000 & 171793 & 21 & 26 & $89 \cdot 6$ \\
\hline & $2 \cdot 4$ & 3051700 & 130000 & 84254 & 184000 & 703660 & 23 & 30 & $81 \cdot 6$ \\
\hline & 8 & 9736000 & 140000 & 253803 & 760000 & 2372579 & 24 & 32 & $77 \cdot 4$ \\
\hline \multirow[t]{2}{*}{ Paros } & $3 \cdot 6$ & 4412050 & 125000 & 116256 & 274000 & 1019677 & 23 & 29 & $81 \cdot 0$ \\
\hline & 36 & 45168500 & 180000 & 495863 & 3420000 & 10031458 & 23 & 29 & $77 \cdot 2$ \\
\hline \multirow[t]{4}{*}{ Naxos } & $1 \cdot 2$ & 1547350 & 90000 & 49894 & 64000 & 358257 & 23 & 29 & $82 \cdot 0$ \\
\hline & $7 \cdot 56$ & 9146805 & 140000 & 239877 & 718200 & 2242055 & 24 & 32 & $77 \cdot 5$ \\
\hline & 36 & 45168500 & 180000 & 495863 & 3420000 & 10031458 & 22 & 28 & $80 \cdot 8$ \\
\hline & $32 \cdot 2$ & 39612725 & 160000 & 413195 & 3059000 & 9091762 & 23 & 29 & $78 \cdot 2$ \\
\hline \multirow[t]{4}{*}{ Andros } & $1 \cdot 575$ & 1994959 & 90000 & 57772 & 149625 & 531915 & 26 & 37 & $72 \cdot 6$ \\
\hline & 23 & 28588375 & 155000 & 315861 & 2185000 & 6843614 & 24 & 31 & $75 \cdot 3$ \\
\hline & $32 \cdot 2$ & 40589725 & 160000 & 429208 & 3059000 & 9498439 & 23 & 30 & $76 \cdot 9$ \\
\hline & $32 \cdot 2$ & 39099725 & 160000 & 429208 & 3059000 & 9513074 & 24 & 32 & $74 \cdot 2$ \\
\hline \multirow[t]{4}{*}{ Tinos } & 0.4 & 547450 & 72500 & 21491 & 38000 & 111300 & 20 & 23 & $93 \cdot 8$ \\
\hline & $1 \cdot 8$ & 2228525 & 77500 & 55622 & 126000 & 489508 & 22 & 27 & $84 \cdot 5$ \\
\hline & $4 \cdot 5$ & 5526313 & 120000 & 981500 & 427500 & 1795543 & 32 & 51 & $62 \cdot 0$ \\
\hline & $25 \cdot 3$ & 3982081 & 150000 & 289764 & 2403500 & 7561655 & 24 & 32 & $73 \cdot 7$ \\
\hline \multirow[t]{5}{*}{ Mykonos } & 0.33 & 473896 & 72500 & 22279 & 23100 & 101345 & 21 & 25 & $91 \cdot 0$ \\
\hline & 0.9 & 1191263 & 75000 & 38434 & 63000 & 249053 & 20 & 25 & $89 \cdot 6$ \\
\hline & $1 \cdot 8$ & 2233525 & 80000 & 65658 & 126000 & 509316 & 22 & 28 & $82 \cdot 9$ \\
\hline & $1 \cdot 8$ & 2233525 & 80000 & 65658 & 126000 & 509316 & 22 & 28 & $82 \cdot 9$ \\
\hline & $1 \cdot 2$ & 1547350 & 80000 & 52660 & 84000 & 385844 & 23 & 31 & $80 \cdot 8$ \\
\hline
\end{tabular}




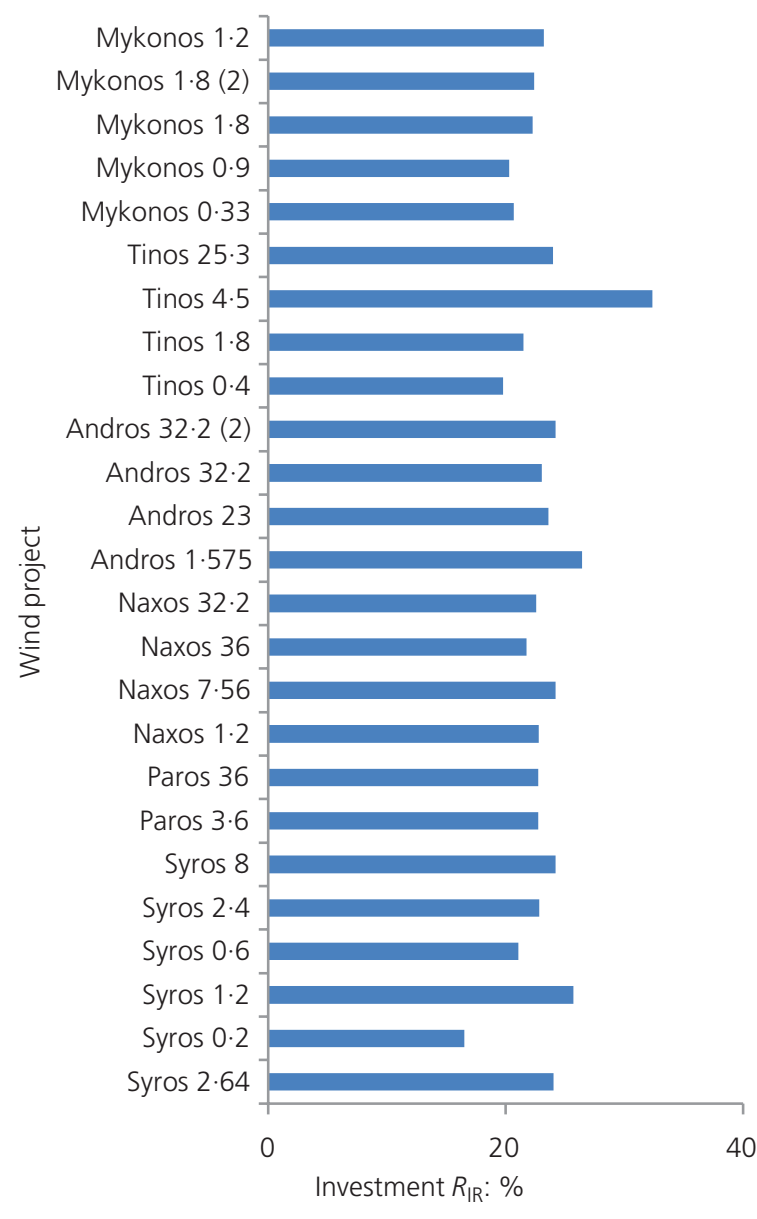

Figure 11. $R_{\mathbb{R}}$ factor for wind projects in the Cycladic islands

Thermal power cost in the islands if oil-fired stations continued their operation would reach $€ 190$ million in 2030, and the total cost between 2017 and 2030 would exceed $€ 2.03$ billion. In contrast, the total cost from wind power will reach just $€ 79 \cdot 8$ million by 2030, including exports from the Cyclades to the mainland. Electricity costs for the Cycladic area will descend to $€ 71.7$ million exclusively from wind power, resulting in $€ 118.3$ million savings compared to the BAU scenario. The aggregation of the annual wind power cost for the 13-year period is estimated to be $€ 711$ million (including exports), while the wind power cost for the Cycladic region only will be $€ 657$ million.

Andros and Tinos, already interconnected, and the rest of the islands, following their interconnection, import electricity from natural gas power stations in the mainland, with costs equal to $€ 0 \cdot 72 / \mathrm{MWh}$ (HIPTO, 2013), as long as wind power generation does not cover demand. Overall, taking into account natural gas, thermal generation from local power stations and wind costs, the total cost savings were estimated to be $€ 1.4$ billion compared to the BAU scenario from 2017 to 2030. Based on this projection, the cost for the interconnection, which is $€ 400 \cdot 17$ million, could be repaid in approximately 4 years' time.

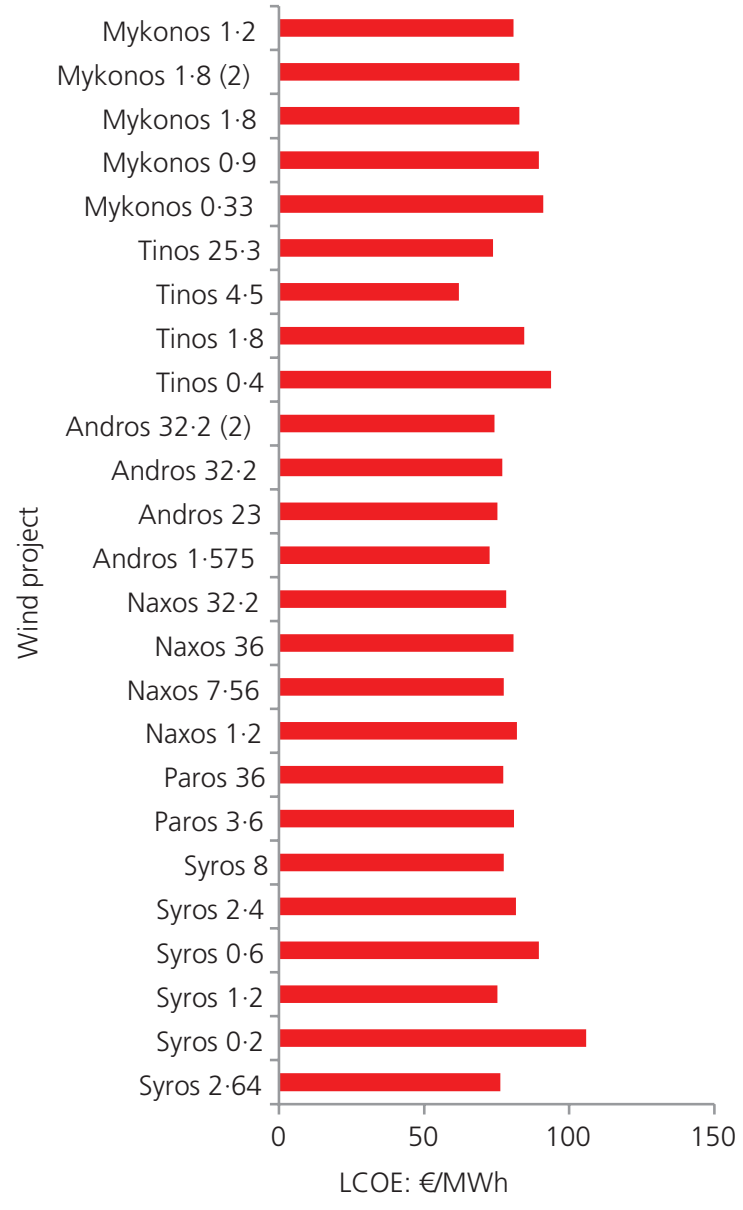

Figure 12. LCOEs for wind projects in the Cycladic islands

\section{Carbon dioxide emissions}

Carbon dioxide emissions from the electricity sector in the Cycladic islands reached almost 0·35 Mt carbon dioxide in 2013. As indicated by the Intergovernmental Panel on Climate Change methodology, 'oil carbon intensity' equals $73 \cdot 3 \mathrm{~kg}$ carbon dioxide/GJ (Blanco et al., 2014). The carbon dioxide intensity factor for oil thermal power plants in an APS with a capacity factor of $30 \%$ is configured to be $0.88 \mathrm{t}$ carbon dioxide/MWh. Assuming the same approach for natural gas power stations in the mainland, with a capacity factor of $53 \%$ and a carbon dioxide intensity equal to $56 \cdot 1 \mathrm{~kg}$ carbon dioxide/GJ, emissions per megawatt-hour are configured to $0 \cdot 381 \mathrm{t}$ carbon dioxide.

The interconnection project will contribute to the gradual shutdown of the existing oil-fired power stations in the area (181.36 MW). Following the wind energy development plans, the carbon dioxide footprint in the area will be abolished by 2025 (Figure 14), when annual demand will meet supply from alternative power sources. From 2025 and onwards, as zerocarbon dioxide electricity from wind exceeds power demand in the area (on an annual basis), renewable power exports replace power from gas power stations on the mainland. Therefore, wind 


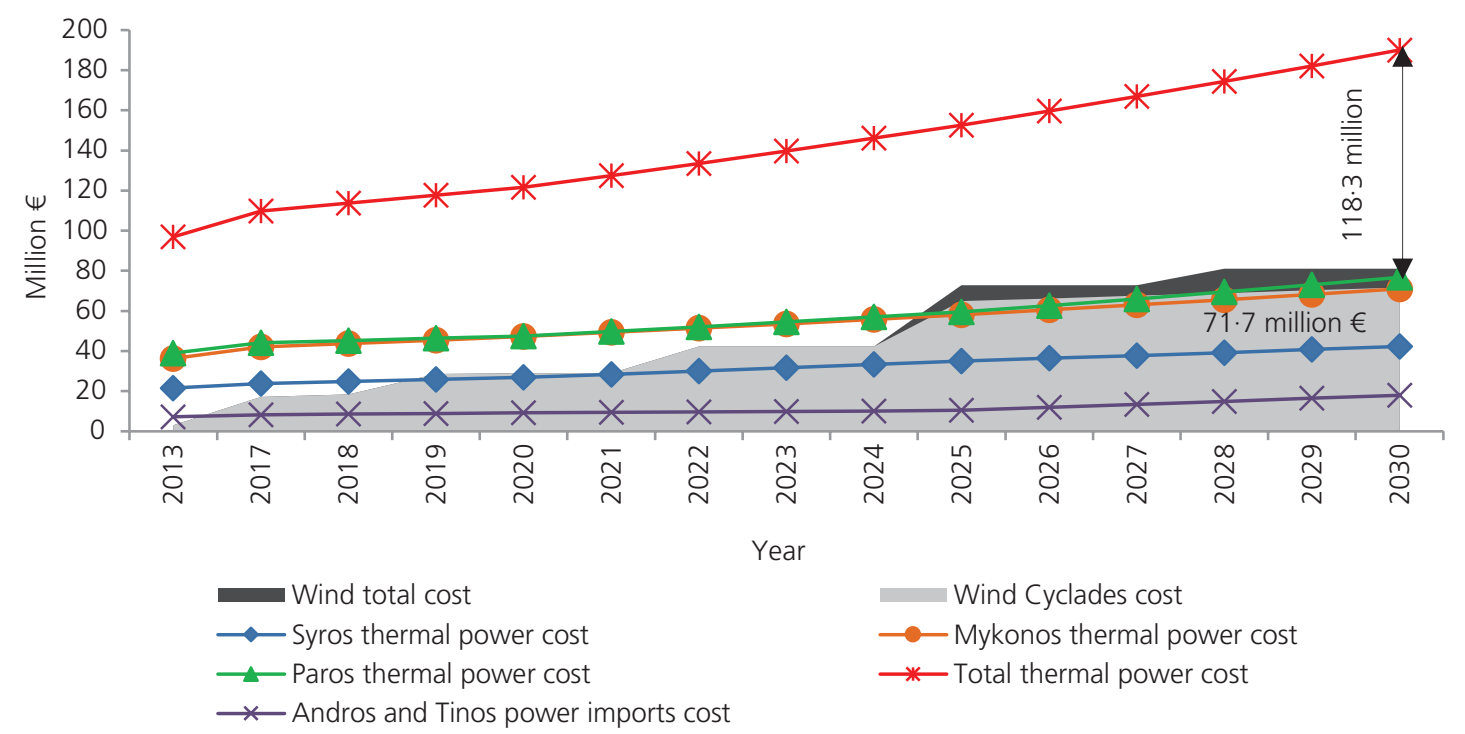

Figure 13. APS costs compared to wind power cost from 2017 to 2030

energy imported from the Cycladic islands contributes to the national battle against climate change and the fulfilment of the environmental commitments for $20 \%$ emission reduction in 2020 and $40 \%$ in 2030 (European Commission, 2009, 2014). Overall, after 2017, wind energy generated in the Cyclades avoids the emissions of $6.003 \mathrm{Mt}$ carbon dioxide in the case where wind replaces oil (no interconnection scenario) and $2.757 \mathrm{Mt}$ carbon dioxide in the case where wind replaces natural gas imports from the mainland following the interconnection (Figure 15).

\section{Conclusions}

The Cyclades interconnection project demonstrates a state-ofthe-art electrical engineering project, interconnecting the three isolated electrical networks of Syros, Mykonos and Paros-Naxos with two interconnected islands, Andros and Tinos, and the Greek national grid system.
Beyond the enhancement of the local power network and energy security improvement, this study proves through an action plan that interconnecting the Cycladic islands will provide both economic and environmental benefits to the Greek energy sector. By selecting information for the wind speed potential of the area, current and future licensed projects as well as the technical characteristics of the interconnection in parallel with the wind energy development plan by the Hellenic Independent Power Transmission Operator, an action plan is proposed for developing $258.6 \mathrm{MW}$ of wind farms in these six islands. Wind farms will supply $772.5 \mathrm{GWh}$ of clean energy to the national grid system in 2030, bringing multiple benefits of shifting to renewable power.

Following an economic life cycle analysis for wind projects in the Cycladic islands, it was concluded that wind projects in Cycladic islands present exceptionally high $R_{\mathrm{IR}}$ factors with mean values

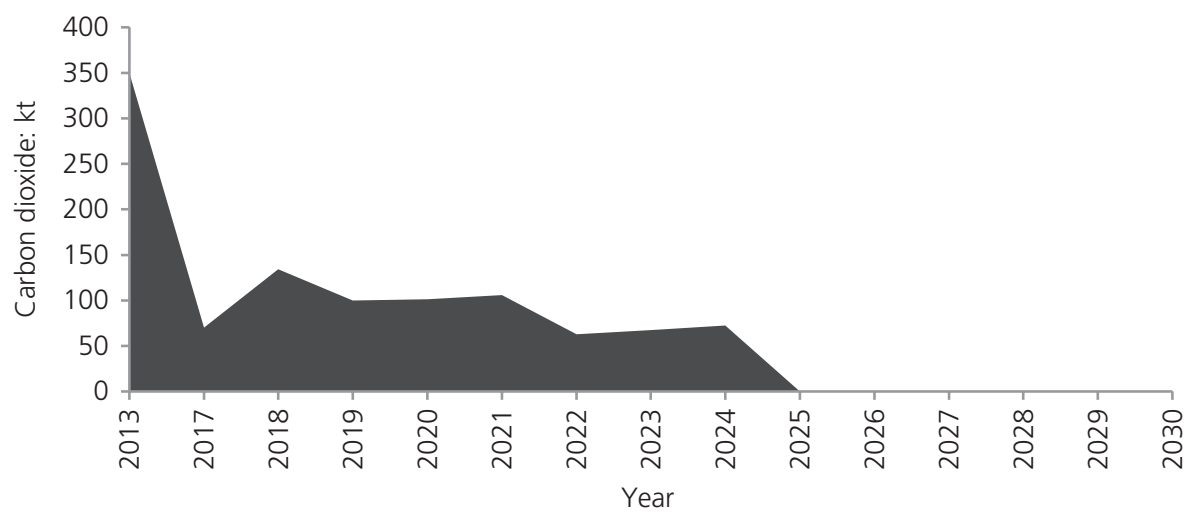

Figure 14. Carbon dioxide emissions projection in the Cycladic Islands from 2017 to 2030 


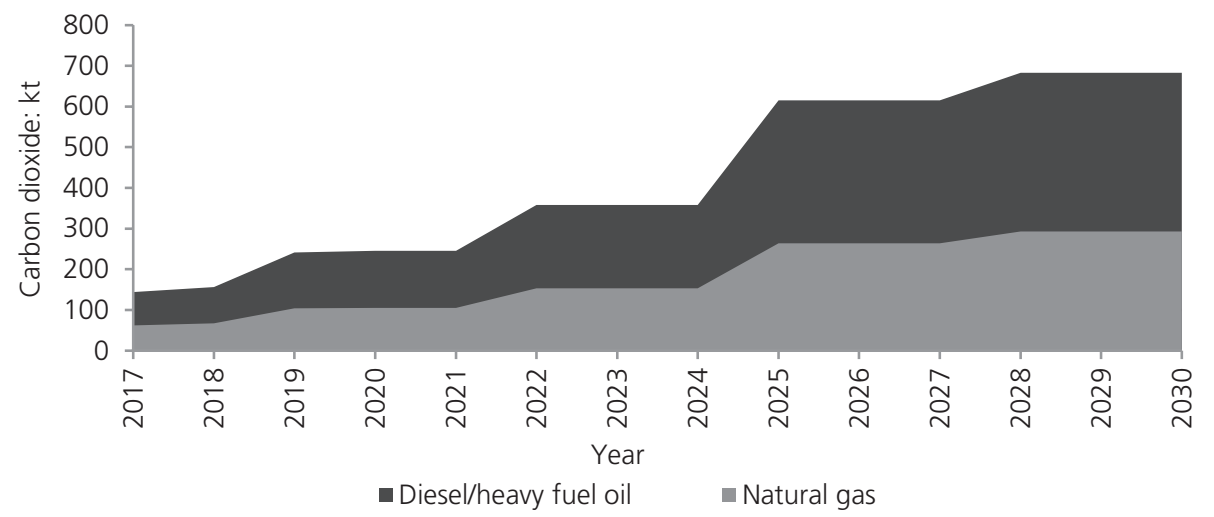

Figure 15. Carbon dioxide emissions reduction from wind generation in the Cycladic Islands from 2017 to 2030

equal to $23 \%$ and average levelised costs equal to $€ 80 \cdot 9 / \mathrm{MWh}$. By 2030 , power generation costs will be reduced by $€ 118 \cdot 3$ million, while the total reduction from replacing oil-fired thermal power with wind and natural gas will reach $€ 1 \cdot 4$ billion between 2017 and 2030 .

Furthermore, wind energy will play a key role in the overall emission reduction. It is projected that by 2025 , carbon dioxide emissions will be abolished on an annual balance in the area. Additionally, at a national level wind energy generated in Cyclades will attain 6.003 Mt carbon dioxide reduction between 2017 and 2030.

By aiming to overcome barriers related to wind energy development, the transformation of the Cycladic islands into a wind energy hub will assist Greece in achieving its EU environmental commitments as well as enhancing profitability and competitiveness to the Greek energy market.

\section{Relevance of the work}

This paper aims to offer an overview of the wind energy sector in a non-interconnected area and its transformation following the interconnection. It presents a contemporary electrical engineering project which focuses on the interconnection of four noninterconnected Greek islands with the mainland. The reader acquires a techno-economic understanding of the wind energy potential in the region. This study presents a realistic action plan for wind energy development based on data collection and projections from public authorities. The methodologies are based on Weibull distribution and life cycle cost analysis. It provides estimations for investment factors, future power costs and emissions. This paper shows that island interconnection projects are feasible and provide environmental and economic benefits.

\section{REFERENCES}

ABB (2013) http://new.abb.com/gr (accessed 06/09/2016).

Akpinar EK and Akpinar S (2005) An assessment on seasonal analysis of wind energy characteristics and wind turbine characteristics. Energy Conversion and Management 46(11-12): 1848-1867, http://dx.doi.org/10.1016/j.enconman.2004.08.012.
Alstom (2013) http://www.alstom.com/ (accessed 06/09/2016). Badgujar SG, Dwivedi AK and Kushwaha SS (2013) Life cycle cost analysis of small wind power. Global Journal of Researches in Engineering Industrial Engineering 13(3-G).

Bank of Greece (2015) Monthly Inflation Factors for Greece (1959-2015). Bank of Greece, Athens, Greece. See http:// www.bankofgreece.gr (accessed 05/06/2015).

Blanco G, Gerlagh R, Suh S et al. (2014) Drivers, trends and mitigation. In Climate Change 2014: Mitigation of Climate Change - Contribution of Working Group III to the Fifth Assessment Report of the Intergovernmental Panel on Climate Change (Edenhofer OR, Pichs-Madruga Y, Sokona EF et al. (eds)). Cambridge University Press, Cambridge, UK, pp. 351-354.

Binopoulos E and Haviaropoulos P (2016) Environmental Impact of Wind Energy Projects Myths \& Reality. Centre for Renewable Energy Resources and Efficiency (CRES), Athens, Greece.

Celik AN (2003) Energy output estimation for small-scale wind power generators using Weibull-representative wind data. Journal of Wind Engineering and Industrial Aerodynamics 91(5): 693-707, http://dx.doi.org/10.1016/S0167-6105(02)00471-3.

Chang TJ, Wu YT, Hsu HY et al. (2003) Assessment of wind characteristics and wind turbine characteristics in Taiwan. Renewable Energy 28(6): 851-871, http://dx.doi.org/10.1016/ S0960-1481(02)00184-2.

Communication Systems, National Technical University of Athens, CNR/ISMAR et al. (2004) Wind and Wave Atlas of the Mediterranean Sea. Western European Armaments Organization Research Cell, Brussels, Belgium.

CRES (Centre for Renewable Energy Sources) (2003) Theme Maps for Exploiting the Economical and Technical Wind Energy Potential in Greece. Centre for Renewable Energy Sources, Athens, Greece. See http://www.cres.gr/kape/datainfo/maps. htm (accessed 21/05/2016).

Enercon (2013) See http://www.enercon.de/en/home/ (accessed 22/09/2016).

Energy Register (2014) Map of RES stations. Energy Register, Athens, Greece. See http://www.en.energyregister.gr/ (accessed 02/09/2015). 
Eurelectric (2012) EU Islands: Towards a Sustainable Energy Future. Union of the Electricity Industry-Eurelectric, Brussels, Belgium.

European Commission (2009) The 2020 Climate and Energy Package. European Commission, Brussels, Belgium. See http://ec.europa.eu/clima/policies/package/index_en.htm (accessed 26/03/2015).

European Commission (2014) 2030 Framework for Climate and Energy Policies. European Commission, Brussels, Belgium. See http://ec.europa.eu/clima/policies/2030/index_en.htm (accessed 12/10/2015).

Gamesa (2014) http://www.gamesacorp.com/en/ (accessed 06/09/2016).

Gras Savoye Willis (2012) http://grassavoyewillis.gr/en/ (accessed 01/01/2012).

Hatziargyriou N, Papathanasiou S, Vitellas I et al. (2012) Energy Management in the Greek Islands. CIGRE, Paris, France, Study Committee C6 Distribution Systems and Dispersed Generation, session paper C6-303.

HEDNO (Hellenic Electricity Distribution Network Operator) (2013) Statistical Database for Power Generation in the NII (2009-2013). HEDNO, Athens, Greece.

HEDNO (2014) Monthly Reports of RES \& Thermal Units in the Non-interconnected Islands - September. HEDNO, Athens, Greece. See http://www.deddie.gr/en/themata-tou-diaxeiristi-midiasundedemenwn-nisiwn/miniaia-deltia-ape-kai-thermikisparagwgis-sta-mi-diasundedemena-nisia (accessed 06/09/2016).

Hellenic Republic (1999) Law 2773: Liberalization of the Greek Electricity Market and Regulation of Energy Policy. Hellenic Republic, Athens, Greece.

Hellenic Republic (2006) Law 3468/2006: Electricity Generation from Renewable Energy Sources and Combined Heat and Power and Other Regulations. Hellenic Republic, Athens, Greece.

Hellenic Republic (2008) Ministerial Decisions for Spatial Planning and Sustainable Development in Greece FEK 2464. Hellenic Republic, Athens, Greece.

Hellenic Republic (2010) Law 3851/2010: Accelerating the Development of Renewable Energy Sources to Deal with Climate Change and Other Regulations in Topics Under the Authority of Ministry of Environment, Energy and Climate Change. Hellenic Republic, Athens, Greece.

Hellenic Republic (2011a) Law 4014: FEK 209 Environmental Licensing. Hellenic Republic, Athens, Greece, p. 36.

Hellenic Republic (2011b) Law 4001: Electricity Market Operation and Natural Gas, Research and Production, Gas Transmission Grid and Other Regulations. Hellenic Republic, Athens, Greece.

Hellenic Republic (2013) Law 4172: Income Tax Rate, Direct Measures of Implementation for Laws 4046/2012, 4093/2012 and 4127/2013. Hellenic Republic, Athens, Greece.

Hellenic Republic (2014a) Law 4254 -Measures for the Support and Development of Greek Economy in the Framework of Applying L. 4046/2012. Hellenic Republic, Athens, Greece.

Hellenic Republic (2014b) Ministerial Decision N. 357/2014 FEK 1873. Hellenic Republic, Athens, Greece, pp. 23627-23642. See http://www.et.gr/idocs-nph/search/pdfViewerForm.html?
args=5C7QrtC22 wEc63YDhn5AeXdtvSoClrL8HrWp6VkY B5y4ndCieBbLVuJInJ48_97uHrMts-zFzeyCiBSQOpYn T00MHhcXFRTsm0kfWRq_UrzlAVseuqZNypMCQE7 sMk3xe5eY0PmYFWk (accessed 12/03/2015).

Hellenic Republic (2014c) Ministerial Decision N. 313/2014, FEK 1836, Issue B. Hellenic Republic, Athens, Greece. See http:// www.et.gr/idocs-nph/search/pdfViewerForm.html?args= 5C7QrtC22wEc63YDhn5AeXdtvSoClrL8t3VVDiksYNsfP1 Rf9veiteJInJ48_97uHrMts-zFzeyCiBSQOpYnTy36MacmUFC x2ppFvBej56Mmc8Qdb8ZfRJqZnsIAdk8Lv_e6czmhEembNm ZCMxLMtV3-cppbEQmLj6hXvYDyWdbPQUIPL6_Bq_xP 6C1rf05a (accessed 03/01/2015).

HIPTO (Hellenic Independent Power Transmission Operator) (2013) Initial Ten Year Development Plan for the Transmission System (2014-2023) Annex 1. Independent Power Transmission Operator, ADMIE, Athens, Greece. See http://www.rae.gr/site/file/ categories_new/about_rae/activity/global_consultation/ history_new/14052013?p=file\&i=1 (accessed 12/03/2015). HIPTO (2014) Ten Year Development Plan for the Transmission System (2014-2023). ADMIE, Athens, Greece. See http:// www.admie.gr/uploads/media/DPA_20142023_Prokatarktiko_Schedio.pdf (accessed 05/01/2015).

Hellenic Statistical Authority (2011) Demographic and Social Characteristics of the Resident Population of Greece. Hellenic Statistical Authority, Piraeus, Greece. See http://www.statistics. gr/portal/page/portal/ESYE/PAGE-themes?p_param=A1602 $\&$ r_param $=$ SAM01\&y_param $=2011 \_00 \&$ mytabs $=0$ (accessed 10/09/2014).

Lu L, Yang H and Burnett J (2002) Investigation on wind power potential on Hong Kong islands - an analysis of wind power and wind turbine characteristics. Renewable Energy 27(1): 1-12, http://dx.doi.org/10.1016/S0960-1481(01)00164-1.

Lun IY and Lam JC (2000) A study of Weibull parameters using long-term wind observations. Renewable Energy 20(2): 145-153, http://dx.doi.org/10.1016/S0960-1481(99)00103-2.

Maroulis G (2013) Electricity Grid Issues in Greece. RES Legal, Brussels, Belgium. See http://www.res-legal.eu/search-bycountry/greece/summary/c/greece/s/res-e/sum/140/lpid/139/ (accessed 13/04/2015).

MEECC (Hellenic Republic-Ministry of Environment Energy Climate Change) (2014a) 6th National Communication and 1 st Biennial Report under the United Nations Framework Convention on Climate Change. Ministry of Environment Energy and Climate Change, Athens, Greece.

MEECC (2014b) Register for Power Stations and Operational Power Stations. Ministry of Environment Energy and Climate Change, Athens, Greece.

Nexans (2011) http://www.nexans.gr/eservice/Greece-el_GR/ navigate_-16/Global_expert_in_cables_and_cabling_systems. html (accessed 06/09/2016).

Nilsson J and Bertling L (2007) Maintenance management of wind power systems using condition monitoring systems - life cycle cost analysis for two case studies. IEEE Transactions on Energy Conversion 22(1): 223-229, http://dx.doi.org/10.1109/ TEC.2006.889623. 
NTUA (National Technical University of Athens) (2008) Final Report 'Strategic Plan for the Interconnection of Non Interconnected Islands' to the Regulatory Authority for Energy of the Hellenic Republic. Ntua, Athens, Greece. See http:/www.rae.gr/site/file/categories_new/about_rae/ activity/research/report9? $\mathrm{p}=$ files\& $\mathrm{i}=0$ (accessed 18/09/2015).

Persaud S, Flynn D and Fox B (1999) Potential for wind generation on the Guyana coastlands. Renewable Energy 18(2): 175-189, http://dx.doi.org/10.1016/S0960-1481(98)00793-9.

Puglia G (2013) Life Cycle Cost Analysis on Wind Turbines. Department of Energy and Environment, Chalmers University of Technology, Gothenburg, Sweden, p. 73.

RAE (Regulatory Authority for Energy) (2004) Paper for the Long-term Meet Fulfilment of Energy Demand in the Cyclades Area. RAE, Athens, Greece. See http://www.rae.gr/old/cases/ C11/O-6720.pdf (accessed 06/09/2016).

RAE (2014a) Geospatial Map for Energy Units and Requests. RAE, Athens, Greece. See http://www.rae.gr/geo/index.php? lang=EN (accessed 06/09/2016).

RAE (2014b) Renewable Energy Resources. RAE, Athens, Greece. See http://www.rae.gr (accessed 21/06/2015).

Ragheb M (2014) Wind Energy Conversion Theory, Betz Equation. University of Illinois at Urbana-Champaign, Urbana-Champaign, IL, USA. See http://mragheb.com/NPRE $\% 20475 \% 20$ Wind $\% 20$ Power $\% 20$ Systems/Wind\%20Energy $\%$ 20Conversion\%20Theory\%20Betz\%20Equation.pdf (accessed 09/06/2016).

Ragheb M (2015) Wind Shear, Roughness Classes and Turbine Production. University of Illinois at Urbana-Champaign, Urbana-Champaign, IL, USA. See http://mragheb.com/NPRE $\% 20475 \% 20$ Wind $\% 20$ Power $\% 20$ Systems/Wind $\% 20$ Shear $\%$ 20Roughness $\% 20$ Classes $\% 20$ and $\% 20$ Turbine $\% 20$ Energy\% 20Production.pdf (accessed 23/03/2016).

Regeneris Consulting and the Tourism Company (2014) Study into the Potential Economic Impact of Wind Farms and
Associated Grid Infrastructure on the Welsh Tourism Sector. Regeneris Consulting Ltd, Manchester, UK.

Schwabe P, Lensink S, Hand M et al. (2011) IEA Wind Task 26. Work Package 1, Final Report. National Renewable Energy Laboratory, Golden, CO, USA. See http://www.nrel.gov/docs/ fy11osti/48155.pdf (accessed 06/09/2016).

Seguro JV and Lambert TW (2000) Modern estimation of the parameters of the Weibull wind speed distribution for wind energy analysis. Journal of Wind Engineering and Industrial Aerodynamics 85(1): 75-84, http://dx.doi.org/10.1016/S01676105(99)00122-1.

Tai $L$ and Wen-rui W (2009) Life cycle analysis on economic operation of wind farm. 2009 Asia-Pacific Power and Energy Engineering Conference, Wuhan, China.

The Tourism Company (2012) The Impact of Wind Turbines on Tourism - a Literature Review. The Tourism Company, Ledbury, UK. See http://www.anglesey.gov.uk/Journals/2012/ 10/30/the-impact-of-wind-turbines-on-tourism.pdf (accessed 09/12/2015).

Torres Silva CE (2008) Factors Influencing the Development of Local Renewable Energy Strategies: The Cases of Lolland and Samsø Islands in Denmark. MSc Thesis, Lund University, Lund, Sweden.

Voltera (2013) Section 4 - Wind Farm of 30 MW Capacity in 'Halkidonio', Municipality of Rigas Feraios, Thessalia \& Sterea Ellada, District of Magnisia. Voltera, Athens, Greece.

Weisser D (2003) A wind energy analysis of Grenada: an estimation using the 'Weibull' density function. Renewable Energy 28(11): 1803-1812, http://dx.doi.org/10.1016/S09601481(03)00016-8.

Zafeiratou E and Spataru C (2015) Investigation of high renewable energy penetration in the island of Syros following the interconnection with the national grid system. Energy Procedia 83: 237-247, http://dx.doi.org/10.1016/j.egypro. 2015.12.178.

\section{HOW CAN YOU CONTRIBUTE?}

To discuss this paper, please email up to 500 words to the editor at journals@ice.org.uk. Your contribution will be forwarded to the author(s) for a reply and, if considered appropriate by the editorial board, it will be published as discussion in a future issue of the journal.

Proceedings journals rely entirely on contributions from the civil engineering profession (and allied disciplines). Information about how to submit your paper online is available at www.icevirtuallibrary.com/page/authors, where you will also find detailed author guidelines. 